\title{
Strategy of Regional Development Policy Based on Potential Local toward Shifting Economic Structure of Bantaeng Regency
}

\author{
M. Said Saggaf \\ Faculty of Public Administration, State University of Makassar, Indonesia \\ E-mail: agustitantu@yahoo.com
}

Received: September 22, 2013 Accepted: October 10, 2013

doi:10.5296/emsd.v2i2.4574 URL: http://dx.doi.org/10.5296/emsd.v2i2.4574

\begin{abstract}
Regional development policies based on local potential triggers a shift in the economic structure of Bantaeng South Sulawesi province. Shift in the structure of the economy is a rapid change in the economic structure as a policy strategy synergizing system of the various sectors in the regions that have an impact on employment, public services, and public participation. The question is what strategy is used to increase the effectiveness of regional development policies impact the shift in the economic structure Bantaeng?. The method used was descriptive qualitative analysis method. The research finding found six interrelated policy strategy to streamline the structure of the economic impact of shifting district. These six strategies are (1) developing a system that is reliable and trustworthy service, (2) managing the system and working mechanism of the holistic autonomous regional government, (3) optimizing the use of information technology and the role of the business community and the public, (5) developing capacity human resources (HR) through increased e-literacy communities, and (6) implementing systematic development through realistic and measurable stages. It can be concluded hypothetically that: If the policy of regional development based on local potential successfully triggers a shift of economic structure, it would require another six policy strategies system for effective regional development policy impact of the shift in the economic structure of the Bantaeng district.
\end{abstract}

Keywords: Regional development policies based on local potential; Strategy policies; shifting economic structure; Bantaeng

\section{Introduction}

Regional development is inseparable from the development of national development. Development activities of the government in these areas are intended in improving national 
development and vice versa. Increasing national development will bring a positive impact on regional development, which can boost revenue, in this case the National Gross Domestic Product (GDP) which would affect the rate of acceleration of regional development. Developments are conducted in the form of planned changes in various aspects of social life by exploiting all the potential of human resources, natural resources, and institutions available in the region. Actually efforts to improve economic growth coupled with efforts to change the economic structure of the dominance of the primary sector towards improving secondary and tertiary sectors becomes very important.

Correspondingly, for the growth and development of a region depends on the dynamics of interaction among the activities in the surrounding areas, because the region has a different development issues across the region with other regions. Differences of the intended development problems are caused by differences in economic potential, sociocultural, demographic, and political backgrounds. Related to differences in the characteristics of each region, the differences invite regional development policies based on local potential. Policies based on intent, every region or area should have its own policy in the planning and implementing development activities in promoting regional development which impacted on the shift of economic structure and the subsequent impact on other development sectors in the region.

In general, the plan includes development policy objectives. Objectives are achieving a rapid increase in per capita income, providing ample employment opportunities, seeking to make it more equitable income distribution, reducing the difference in the rate of growth and development from region to region, and changing the structure of the economy so that it has an impact on the various economic sectors in the regions that contribute directly to GDP.

Ensure reliable planning guarantees the achievement of development goals effectively and efficiently. In essence, the national and regional development is now focused on economic growth, sustainable development, and equitable distribution of income.

Tabel 1. The percentage contribution of GDP Per-Economic Sector of Bantaeng based on Current Prices in 2007-2011 (percent)

\begin{tabular}{|l|l|r|r|r|r|r|}
\hline \multirow{2}{*}{ No. Sectors } & \multicolumn{1}{|c|}{ Year } \\
\cline { 3 - 7 }$(1)$ & \multicolumn{1}{|c}{$(2)$} & \multicolumn{1}{c|}{$(3)$} & \multicolumn{1}{c|}{$(4)$} & \multicolumn{1}{c|}{$(5)$} & \multicolumn{1}{c|}{$(6)$} & \multicolumn{1}{c|}{$(7)$} \\
\hline 1 & Agriculture & 57.43 & 55.91 & 51.87 & 49.79 & 49.13 \\
\hline 2 & Mining \& Quarrying & 0.71 & 0.65 & 0.79 & 0.87 & 0.86 \\
\hline 3 & Manufacturing & 3.32 & 3.15 & 2.95 & 2.80 & 2.67 \\
\hline 4 & Electricity, gas, and water & 072 & 0.73 & 0.65 & 0.64 & 0.57 \\
\hline 5 & Building & 5.54 & 5.15 & 5.54 & 6.14 & 5.78 \\
\hline 6 & Hotel \& Restaurant & 9.98 & 9.98 & 11.23 & 11.32 & 12.43 \\
\hline 7 & Figures and financial & 3.03 & 3.12 & 2.99 & 285 & 295 \\
\hline 8 & communication & 6.29 & 6.31 & 5.93 & 586 & 585 \\
\hline 9 & Rental and business services & 12.99 & 15.01 & 18.05 & 19.75 & 1977 \\
\hline & Services & $\mathbf{1 0 0 . 0 0}$ & $\mathbf{1 0 0 . 0 0}$ & $\mathbf{1 0 0 , 0 0}$ & $\mathbf{1 0 0 , 0 0}$ & $\mathbf{1 0 0 . 0 0}$ \\
\hline
\end{tabular}

Sources: Bantaeng Statistic Centre 


\section{MInstitute Macrothink}

GDP data shows the percentage contribution of a shift of economic structure Bantaeng district. This can be seen in the percentage contribution of each sector. Contribution to the agricultural sector decreased from 49.79 per cent in 2010 to 49.13 percent in 2011 . The opposite occurred in trade, hotels, and restaurants, services sector and transport and communications sectors. These three sectors have added contributions. This illustrated that the decrease in the contribution of the agricultural sector resulting in an increase in the role in several sectors except agriculture. The decrease in the agricultural sector's contribution to total GDP was caused by the sub-sectors that support the agricultural sector which also decreased, beside that there was also an increase in the role of sectors except agriculture in 2011 which is quite significant.

\section{Ideal Dimensions - Normative Policy Strategy Based Regional Development Potential Local}

\subsection{Policy Strategy in the Perspective of Public Administration}

Development of state administration by Mercy (http / / Makassar. Ian.go.id) is one of the important determinants in the public administration system that plays a role in the transformation process focused on achieving value objectives of government. Public administration reform is directed at the implementation of the overall management functions of government that is based on the need for improving the effectiveness and quality of services in accordance with the dynamics of social progress and development challenges. Public administration should have the credibility and accountability of the government to solve problems in an increasingly complex society, nation and state especially in efforts to achieve equitable welfare and enhance the competitiveness of local autonomy within local governance and decentralization. James Wilson (1989) in Kagambirwe Gerald (2012) describes culture as the administration persistent way of thinking about the central tasks of an organization and human relationships within it.

The study of administrative reform is a very important part in the development of developing countries, regardless of the level of development or growth velocity and direction of development. According to Caiden (1991) the emergence of the need for administrative reform as the administration is identified with the effort to improve the efficiency and effectiveness of the organization (Lee, 1980).

Wallis (1989) says that:

Administrative reforms consist of three aspects, namely (1) a change should be an improvement of the previous state; (2) improvement is obtained with a deliberate effort and does not happen by chance; and (3) happened improvements are long-term and sustainable.

In addition of these three aspects, Katz (1987) from the results of a more recent analysis of the state administration in developing countries reveals that efforts to improve the performance of government bureaucracy should include resource responsiveness and effectiveness in service delivery. 
Administrative reform is a conscious and deliberate effort to enhancement behavior of the institutions involved. Zauhar (1996) holds that: The purpose of reform is to improve the administration of the order, to perfect methods, and to improve performance.

Public policy in craving desire by all levels of society is if the policy giving a real impact and supporting the public interest. The decision maker must have sufficient knowledge about the values of the community and the ability to precisely calculate the ratio of costs and possible alternatives. Positive impact on society is because society judge as a government policy that public policy based on the constitution and the laws in force. Public policy is a national policy focused his generation, public policy, and operational policies.

\subsection{Policy Strategy in the Perspective of Regional Development}

Strategy of development of the region is all policy decisions made and carried out for associating system of living community, nation and country. A policy to build a sinergy constructively the components of Government, private and public in development according to Prasetyo (http: www.simpuldemokrasi.com) is a policy which basically describes the decision as an important part of the resources available in the life of community, nation and country. Policy is the result of an agreement that has been formulated through a process that involves all stages of the concept, the idea, and a number of theoretical interests in it. Identified dimensions are interlocked among public policy as the choice of legal action by law, public policy as hypothetical and public policy as the destination (Bridgeman and Davis, 2004).

According to Thomas R. Dye : "public policy is whatever governments choose to do or not to do", or a more concrete definition as written by Peters that "Public policy is the sum of activities of governments, whatever acting directly or through agents, as it has on influence on the lives of citizen".

According to Randall B. Ripley (1989) public policy should be viewed as a process and view the process in a simple model to understand the constellation between actors and interactions that occur within it. ${ }^{1}$ This definition is included in the classification process management because there is a process or action step or activities to achieve goals.

Referring to the Hogwood and Gunn, Bridgman Davis (2004) in Prasetyo (http / www.simpuldemokrasi.com) stated that public policy at least include the following: (1) Field of activity as an expression of general purpose or statements that want to be achieved, (2) certain proposal that reflects the government's decision-making that was chosen, (3) formal authority such as laws or regulations, (4) program, which is a set of activities that include resource use plans and strategies to achieve agency objectives, (5) output which is what the real has been provided by the government, as the product of a particular activity, (6) The theory which explains that if we do X, we will follow Y, (7) The process that took place within a certain time period is relatively long.

There are at least four layers of meaning of public policy that can be understood. The first layers of meaning that the policy is a decision. The second is a series of policy work or public officials. The third is that the policy can be interpreted in the form of sociocultural by 
utilizing a variety of instruments to address public issues. The fourth is that the policy is intended as interaction of state policy and society in order to address public issues. From the above four layers of meaning, the scientists agreed to classify the meaning that has been implemented in the theory of public policy.

Strategy as a form of policy decisions that have an impact in the implementation can also be interpreted from a variety of expert opinions consisting of Thomas R. Dye, Graham Allison, Carl Fredrich, and Willem N. Dunn. They are masters of political science and public administration to develop the study of public administration as an applied art and science.

1) Thomas r. Dye: "public policy is" whatever "goverments choose to do or not to do," or a more concrete definition is said by Erwan Agus Purwanto (1997) in his thesis argue that public policy is always associated with a decision. The Government's decision is devastating to people's lives through policy instruments which are owned by the Government in the form of laws, services, the transfer of funds, tax and budget-budget.

2) Graham Allison (1971) public policy is the result of competition from various entities or departments that exist in a country with government institutions as its main actors are bound by context, the roles, interests, and capacity of the organization.

3) According to Carl Friedrich (1983) is a public policy direction proposed by the action of a person, group or Government is in a particular environment that gives the obstacles and opportunities of the proposed policy to use and overcome in order to achieve a goal or achieving a goal or a particular purpose. In this matter the Government has the right to give a chance to the barriers and the policy. The Government is still authoritative although it could be said the policy has goals and objectives for the benefit of the community. Public policy is the directions that are authoritative for implementing the Government's actions in the jurisdiction of the national, regional and local.

4) William n. Dunn (1981) formulate public policy as a guideline containing the values and norms that have the authority to endorse the actions of the Government in his jurisdiction.

When public policy is set to become a public policy, would become law, would be a government regulation or regulation including The President of the public policy that turned into a law that must be adhered to. Meanwhile, public policy experts define public policy is that everything that is done or not done by the Government, why a policy should be done and what are the benefits for life together should be holistic consideration to such policies contain great benefits for its residents and a small impact and should not give rise to an adverse issue, although there must be some benefits and some were harmedHere it is, the Government should be prudent in determining a policy (Thomas Dye, 1992).

However the policy is derived from the word policy is considered to be a relatively new concept is as said by Michael Hill that The concept of policy has a particular status in the rational model as the highly durable element against which other premises and actions are supposed to be tested for consistency. 


\section{Mll Macrothink}

Environmental Management and Sustainable Development

ISSN 2164-7682

2013, Vol. 2, No. 2

Thus is the policy in the policy system of values is Kybernology and wisdom born of wisdom actors or institutions concerned. Furthermore the policy after going through a thorough analysis of the formulated product into an appropriate policy. In formulating policy, Thomas. Dye introduces a variety of institutional models such as the model, a model of the elite, model groups, models of rational, incremental model, a model of game theory, and public choice models, and model systems.

The next recorded three models proposed Thomas r. Dye, namely: integrated observation model, a model of democratic and strategic model. Associated with the Organization, policies, according to George r. Terry in his book Principles of Management is a comprehensive guide, good oral and writing that gives the public a boundary and direction of target actions which will be performed the leader (Terry, 1964).

According to Robert Eyestone (2002), public policy is seen as a government unit's relationship with its environment. This definition is likely to be biased, as it does not clearly indicate the instrument inside, if there are government interaction with society, government intervention, or there is not a series of phases in the policy.

Another formulation since expressed by Chief (1981), public policy is "an act of sanctions that lead to a particular purpose directed at a specific problem or set of problems are interrelated and affect most of the citizens". This definition included in the classification policy as democratic governance.

According to Anderson the impact of State policy are: (1) That the country's policies have always had a certain goal or a goal-oriented action, (2) that the policy that contains the action or action patterns of governmental officials, (3) that the policy is what it is really done by the Government, (4) state that the policy is positive in the sense that some of the Government's actions regarding a specific issue or is negative in the sense that a decision by government officials of doing things.

Listen to the performance of the Government as long as it shows that the Organization of the Government and the provision of public services is always based on the approach of management strategies based on rationality. According to Wilson (1992), the nationalist strategic management approach is reflected from any organizations or units which have activities in carrying out the outline of his vision, mission statement, long-term planning, the formulation of indicators and success to be achieved, the strategy implementation, monitoring performance, the culture in the wake of an organization, system controls and incentives given to the parties involved on each institution.

\section{Economic Sector Development Policy Strategy Area}

The early 1960s Raul Prebisch successfully build and deploy strategies of distribution of imports. This strategy is in the believe by a condition of imbalance between developed countries and developing countries. The pattern of the relationship between the two groups of countries is the dominant relationships depend on developed countries, where the dominant position and the position of the developing countries depends. Such a pattern of more lucrative developed country, which in turn further widen the gap between the two countries. 
Indonesia is one of the countries that adopted the strategy of distribution of imports. During this strategy in Indonesia has managed to apply changed its economic structure, economic structure of the former in domination by the manufacturing industry sector. Along with that, the pace of Indonesia's economic growth reached a high enough level. The change of economic structure that is Indonesia at that time occurred at the national level; While on the level region, not all regions benefit from the strategy, especially in areas outside Java. merit applied the strategy, has been gradually widened the gap between the economy of Java and other major islands.

\subsection{Development of the Sector Workforce}

The influence of human development or quality human resources to regional economic growth or performance in Indonesia have been examined empirically by Garcia and Soelistianingsih (1998) as well as Wibisono (2001). However, empirical studies on the reverse side, the influence of human development close to the performance of the regional economy in particular is still limited. Empirical study on the limited still sided actually has also become a general trend. As mentioned by Ramirez and his friends (1998), the existing studies are generally put more emphasis on the effect of advances in the quality of human resources towards economic growth, as it also looks from a number of studies that revealed (Meier and Rauch, 2000).

According to Ramirez and his friends, although there is a two-way relationship (twoways relationship) between human capital and economic growth that is already widely accepted, but the specific factors that link it still less is explored systematically.

\subsection{Development of the Natural Resources Sector}

Sylvia Horton (2012) suggests that "the management of human resources has a high priority not only because of cost but also because of the human resource is the dealer of all government activities". Just as the administration of the people and the Government have given way to new public management and governance, so that the traditional personnel management has given way to the management of human resources (HR).

Initially, the new emphasis on maximum volume or value in a sustainable wood sustainably produced timber from Hyde (1980). Later some of the research has been expanded by observing that forests provide some of the goods and services of value, most have been sold and others are still out of the market.

\section{The Actual Dimensions - Economic Impact Shifting the Structure of Emperik District}

Economic development is the effort to raise and sustain increase in gross domestic product (GDP) per capita but still showed the growth rate of the population accompanied the existence of fundamental changes in the economic structure. In the process of economic development, the Government is consciously planned and staged changes toward improvement of livelihood of the community. 


\section{Mll Macrothink}

Environmental Management and Sustainable Development

ISSN 2164-7682

2013, Vol. 2, No. 2

Economic development requires a variety of public policy based on sustained economic growth, equitable development and the equitable distribution of income and the impact on the improvement of welfare in the life of a community, a nation and a country.Specifically other Opinion Samuelson says "economic development can be interpreted as a saying " economic development can be defined as a country's ability in combining human resources, natural resources, capital formation, and the level of technology" (Samuelson, 2010).

Further capital formation, Jhingan said making the construction becomes possible, even with the increased population. Investment in capital equipment not only production, but also increases job opportunities and technical advances that can produce to support the achievement of economies of scale and improve the production spelisiasi.

\subsection{Economic Growth}

Todaro (Lepi. Tarmidi, 2013) defines development as a multidimensional process involving major changes in the structure of social attitudes, institutional national and the acceleration of economic growth, reduction of poverty and the Elimination of unequal absolute.

According to Schumpeter (Suryana, 2012), economic development is not a process of harmonious or way up, but it is a change that is spontaneous and not disjointed. Economic development is primarily caused by changes in the field of industry and trade. Economic development and per-capita income related to national income. Per-capita income is the average income of residents of an area.

Economic growth has a bonding closely with changes in the sectoral structure and high. Any changes in the main component will trigger a structural shift in agricultural activities gradually towards non agricultural sector and from the industrial sector to the service sector. An area that is developing the economic growth process will be reflected in the shift in the traditional sectors of the economy that the agricultural sector will experience a decrease in one hand and the increasing role of non-agricultural sectors from the other side (Todaro, 1997).

\subsection{The Shifting Economic Structure Have an Impact on Government Policy}

A shift in the economic structure is an absolute thing in an area that is evolving, and thus needed to spur an acceleration of economic growth in economic activity dominated the countryside in order to move towards the urban economy in industrial activities and services. Basically theories about the shifting economic structure explain the occurrence of changes in the structure of the developing country dominated the economy activity. Generally, a shift in the economic structure is characterized by the transition and the shift of economic activities from the primary production sectors (agriculture) to the secondary sector (industry, manufacturing, construction and service sector).

Kuznest (Sukirno, 2013) suggests that:

The shift in the economic structure in the process of development is not only due to the change in percentage of residents who work in various sector and subsector in economic 


\section{Macrothink}

Environmental Management and Sustainable Development

ISSN 2164-7682

2013, Vol. 2, No. 2

development, but due to changes in the contributions of various sectors of the economy to the national product in the development process.

Kuznets concluded that changing the donation the agricultural sector, industrial sector, and the service sector to national production. The pattern of these changes include: (1) the agricultural sector's contribution to national production is declining. (2) the industrial sector's contribution to national production increase, (3) the service sector's contribution to the national product did not undergo the change means inconsistent and it changes its nature.

The theory of the transformation of the structure of basically admitting the existence of the stages of production changes from the primary sector to the secondary sector and the tertiary sector to end up. Clark (1940) in the Budiharsono (2010), said that the economic growth that followed by this transformation can be achieved through an increase in labor productivity in every sector and the transfer of labour from low productivity sectors to high-productivity sectors.

Further in the analysis of Kuznets in Sukirno (2013) are divided into several sectors: 1 agricultural sector), 2), the industrial sector is divided into five subsector subsector, namely electricity, gas and water supply, transport, and 3 services) sector is divided into five sectors namely Commerce, banks, Government and defense, house rental as well as individual services.

\section{Research Methodology}

\subsection{The Location Of Research}

The research was carried out in Bantaeng,

\subsection{Research Approach}

This study used a phenomenological approach

\subsection{Data Source}

The source of the data in this study consisted of:

- The primary source of Data.

- $\quad$ The secondary Data source.

\subsection{Focus Problem}

That focus of his research was the issue of how to impact policy development based on local potential area of growth 1900 Regency economic sectors.

\subsection{Research Instrument}

This research Instrument was the researchers themselves

\subsection{Data Collection and Validation Techniques}

Data collections techniques used were: 


\section{Macrothink

1) Interview Techniques

2) Observation.

3) Documentation.

\subsection{Data validation is performed by:}

1) Extension of the observation.

2) Increased persistence of researchers in the observation and interview.

3) Triangulation of sources.

\subsection{Method of Data Analysis}

Analytical method used is descriptive qualitative methods of analysis

Next do triangulation that checked the validity of the data that utilized something else outside of that data for the purposes of checking or as a comparison against the data.

\subsection{Place and Time of Research}

This research was conducted in Bantaeng Regency as a component of growth in the region and the province of South Sulawesi

\subsection{Research Methods}

This type of research was qualitative, descriptive.

\subsection{Data Collection Methods}

Data collection methods used to obtain the data required were as follows: (1) interview (interview), (2) a list of questions (3) study the documentation,

\subsection{Types and Sources of Data}

Types and sources of data used in this study were: (1) primary data, (2) secondary data.

\section{Result and Discussion}

\subsection{The Dimensions of the Strategy of Economic Structure Shift Impact Streamline District}

A shift in the economic structure of the district is the ongoing changes in 1900 lived at a time when the world is undergoing a transformation to the information society. Information technology advances rapidly and the potential of such a widely used, open up opportunities for access, management, and utilization of information in large volumes in a fast and accurate. Reality has shown that the use of electronic media is a very important factor in many international transactions, mainly in trade transactions. Inability to adapt to the global trend will bring the nation into the abyss Indonesia digital divide, namely isolated from global developments due to not being able to make use of the information. Therefore the Central structuring we conducted should be also directed to encourage the people of Indonesia towards the information society. 


\subsection{Government Expected}

The above changes are demanding the formation of a national clean, transparent, and able to respond to the demands of change effectively and sustainably. The Government should be able to meet the two demands of different modalities, but closely related, namely:

a. The community demands of public service that meets the interests of the wider community across the region who are reliable and trustworthy, as well as easily accessible interactively.

b. Community wants their asiprasi heard so the Government must facilitate the participation of the public in dialogue and in the formulation and implementation of policies.

To answer these challenges over the Government and the Government of the autonomous region should be able to form a strategic dimension to the Organization's governance, governance and process management system that works, among others, include:

a. The application of the system and the work process based on the order of modern bureaucracy. Because the system and process of a rigid work unlikely to answer a complex and dynamic change, which always needs to be addressed quickly. Therefore in the future the Government should develop systems and processes work more pliable to facilitate various forms of a complex interaction with the community, the business world, and the international community.

b. The Government's management system is a hierarchical system for the authority and command of the conical cutting and long. To satisfy the needs of an increasingly diverse society in the future should the organization management system developed a network that can shorten the lines of decision making as well as expanding the range of control.

c. The Government should also relax the separator walls that limit interaction with the private sector; Government organizations must be more open to forming partnerships with the business world (public-private partnership).

d. The Government should be able to take advantage of advances in information technology to enhance the ability to cultivate, manage, transmit, and distribute information and public services.

Thus the Government and the autonomous regional Government should immediately implement process transformation to e-government. Through the transformation process, the Government and the Government of the autonomous region can optimize the utilization of advances in information technology to eliminate the political organization and political bureaucracies, as well as forming a network management system and work processes that allow agencies-government agencies working in integrated to simplify access to all information and public services which should be provided by the Government. Thus the whole country institutions, communities, businesses, and other interested parties may at any time make use of Government information and services optimally. For that it needs a strong leadership in their respective institutions or governmental units so that the process of transformation to e-government can be implemented as well as possible. 


\section{Macrothink \\ Environmental Management and Sustainable Development \\ ISSN 2164-7682 \\ 2013, Vol. 2, No. 2}

First Strategy: Develop a strategy for service system a reliable and trustworthy.

The community expects of public services not integrated by discontinuous boundary organizations and bureaucratic authority. The business world requires an interactive information and support from the Government to be able to respond to market changes and the challenges of global competition quickly. The smooth flow of information to support relations with State institutions, as well as to stimulate community participation is an important factor in the formation of State policy. Therefore, the public service must be transparent, reliable, and affordable by the public at large through a network of communication and information.

Second Strategy: Strategy Setting up the system and autonomous regional government work process holistically.

The achievement of strategy- 1 should be supported by structuring management system and work processes in all government agencies and the Government of the autonomous region. Structuring management system and work procedures should be designed so that the Government can adopt information technology advances quickly. Setup must include a number of individual targets or holistically formed the context for the formation of good Governence.

Three Strategy: Strategy Utilizing information technology optimally.

The implementation of each strategy requires ability in carrying out the transaction, processing, and management of various forms of electronic documents and information in large volumes, corresponding to the highest level. Advances in information technology and the development of communication and information give broad opportunities for government agencies to meet these needs. In order for the utilization of information technology in each instance can form optimal work network, then this strategy through a number of goals that need to be pencapaianny

Four Strategy: Strategy Increase the involvement of the business community and society

The development of public services does not need to be fully addressed by the Government. The participation of the business world can accelerate the achievement of the strategic goal of e-government. Some of the possible participation of the business community as the following need to be optimized.

Five strategy: Develop a capacity strategy human resources (HR), with the increase of e-literacy communities.

Human resources (HR) either as a developer, Manager and users of e-government are factors that determine even a key success of the implementation and development of e-government. To that end, efforts are needed to increase the capacity of human resources and the power to Setup, with a mature and comprehensive planning according to your needs, as well as its implementation is done gradually and sustainably. This is done through the formal and non formal education, as well as the development of the competency standards required in the development and implementation of e-government. 
Six strategy: Carry out development strategy systematically through a realistic and measurable stages.

Any change could potentially give rise to uncertainty. Therefore the development of e-government needs to be planned and implemented systematically through stages that are realistic and measurable targets, so that it can be understood and followed by all parties. Based on the nature of the transaction information and public services provided by the Government through the information network, the development of e-government can be implemented through four (4) phases. The first is the preparation stages include: site creation information in every institution, preparation of HUMAN RESOURCES, preparation means easy access for example provides a means of Multipurpose Community Cente, Cybercafe, SME - Center, and socializing site information to internal and external stakeholders. The second stage of ripening activities which include public information, site creation and manufacture of connectedness with other agencies interface. The third phase of consolidation that includes the transaction site creation activities of public service, and the creation of interoperability of applications and data with other institutions. The last stage of four activities that include usage of making applications to the Ministry which is G2G, G2B and $\mathrm{G} 2 \mathrm{C}$ is integrated.

The Government site and the Government of the autonomous region should be gradually increased leading to the stage -4 . To consider that the higher levels of the site, the required support work processes, management systems, and transaction information between agencies that are increasingly complex. Efforts to raise the level of the site without adequate support, the failure will not only cause a waste but also eliminate the trust of the community.

\section{Conclusion and Advice}

\subsection{Conclusion}

1). Policy development of the region based on local potential influence on the trend of shifting economic structure district 1900 . There are nine sectors which are potentially being counties flagship sector supporting in the construction of Regency Bantaeng. The ninth sector is developed simultaneously with a range of government policies that are implemented with functional and operational management system so that the impact on the economic structure of the district and shifts make the agricultural sector as the biggest contributor to the $(49,09 \%)$ on revenue of the original area (PAD). A shift in the economic structure of the subsequent impact on the absorption of Labor (79 percent) worked in the agricultural sector, public services and public participation in the formulation and implementation of Government policy in Bantaeng.

2). The Trend of shifting economic structure trigger various alternative Bantaeng Regency policies system development strategies from all potential winning impact on increasing labour absorption in various sectors of excellence, expanding access to public services and public participation in various County Government policy Bantaeng. This means in hipotetikal, that the shift in the economic structure which occurs due to development of the region's policy based on local potential, triggered the strategy does impact the absorption of 


\section{Macrothink}

Environmental Management and Sustainable Development

ISSN 2164-7682

2013, Vol. 2, No. 2

labor, the expansion of access to public services, and increased community participation in various County Government policy Bantaeng.

3). If there is a trend of shifting the structure of regional economic development policies in the region because of the potential for local-based, then it happened also increased absorption of labor, the expansion of access to public services, and community participation in various regional development policy

4). The effective area-based development policy local to potential shifts in the economic structure of the district, the more effective labour absorption strategy anyway, access to public services, and community participation in various policy alternatives of local government districts of Bantaeng.

\subsection{Advice}

1) Bantaeng Regency Government needs to establish and develop the flagship sector area in the system, so the pace of development of the sector of mutual support and have an impact on the sustainability of economic development districts.

2) County Government needs to implement E-government in promoting the potential of the sector's flagship areas that have an impact on the absorption of labor, public service, and public participation in various development policies.

3) The County Government needs to carry out various policies related to the flagship sector areas that have an impact on the shift of labour and public service

4) Local governments need a strategy for accelerating development in the aspect of labour, quality of public services, and community participation through E-government strategy of the six interconnected in its implementation.

5) County Government needs to continue to involve stakeholders in the creation of various development policies in order to encourage increased participation in community development policy implementation based on local potential. In terms of leadership, success in implementation of the policy depends on actualizing organizational leadership characteristics, operational leadership, and public leadership in the management of the construction of the district.

\section{References}

BPS Kabupaten Bantaeng. (2011). Produk Domestik Regional Bruto Kabupaten Bantaeng Tahun 2011. Bantaeng: Badan Pusat Statistik Kabupaten Bantaeng.

BPS Provinsi Sulawesi Selatan. (2011). Produk Domestik Regional Bruto Provinsi Sulawesi Selatan Tahun 2011 Makasssar: Badan Pusat Statistik Provinsi Sulawesi Selatan.

Herald. (2012). Trade Policy Impacts Under Alternative Land Market Regimes in Rural China. China Economic Review, 23, 1071-1089. 
Horton, S. (2012). Management Human Resource in Public Sector, University Portsmouth, Inggris.

Jhingan, M. L. (1996). The Economic of Development and Planning, Konark Publishers, India (Delhi). 859 p.

Jamet V. Denhandd and rabert B. Denhandd the News Public Service, Expanded Edition Sevingmot Stening, Axemon, New Yarle. (Terjemahan).

Karyeija, G. (2010). Performance appraisal in Uganda's civil service. Does administrative culture matter? Unpublished $\mathrm{PhD}$ dissertation, University of Bergen

Karyeija, G. (2012). The Impact of Culture on Performance Appraisal Reforms in Africa: The Case of Uganda's Civil Service. Asian Social Science, 8(4), 160-174. http://dx.doi.org/10.5539/ass.v8n4p159

Lucas., E. C., \& Prim, B. K. (2012). Identify the Depressed Regions and Declining Industries In Indonesia Kuala Lumpur Malaysia 3rd Biennial meeting of the Agriculture Economic Society of South East Asia.

Michael, H. (2009). He public policy Pracess, New-York, Person Logam

Owen, E. H. (2012). Bube Management dan Administration, New-York, Palgrave Macmilan.

Robert, L. H., \& Palencher, M. J. (2009). Strategic Issues Management Organization and Public Policy Challenges, California, Second Edition, SAGE publications, Inc. p 424.

Sukirno, S. (2011). Ekonomi Pembangunan, Proses Masalah dan Dasar Kebijakan. Jakarta: Lembaga Penerbit Fakultas Ekonomi Universitas Indonesia.

Suryana. (2012). Ekonomi Pembangunan, Problematika dan pendekatan. Bandung: Salemba Empat.

Sarah, M., \& Denniss, R. (2009). An Introduction to Australian Public Policy, Theory and Practice. Cambridge: Cambridge University Press. pp 281.

Tjokroamidjojo, B. (2009). Pengantar Administrasi Pembangunan. Jakarta: LP3ES.

Todaro, P. M. (1997). Economic Deveploment. Sixth Edition. Addison Wesley Longman Limited. Edinburgh Gate, Harlow, ESSEX CM 20 2JE, England.

Todaro, P. M. (2000). Economic Deveploment. Seventh Edition. Addison Wesley Longman Limited.Edinburgh Gate, Harlow,ESSEX CM 20 2JE, England.

Trias, A. (2009). Perencanaan dan Penyelesaian Masalah Infrastruktur Perkotaan Melalui Integrasi Sig Kolaboratif Dan Sig Partisipasi Publik, Indonesia.

Tony, B., \& Elle H. (2009). Public Management and Governance, New -York and Canada, Routledage.

William, N. D. (2005). Pengantar Analisis Kebijakan Public. University of D, Yogyakarta, Gajah Mada university Press. 


\section{Macrothink \\ Environmental Management and Sustainable Development \\ ISSN 2164-7682 \\ 2013, Vol. 2, No. 2}

Zafrullah, H. (2007). Bureaucratic Elitism in Bangladesh: The Predominance of Generalist Administrators. Asian Journal of Political Science, 15(2), 161-173.

\section{Copyright Disclaimer}

Copyright reserved by the author(s).

This article is an open-access article distributed under the terms and conditions of the Creative Commons Attribution license (http://creativecommons.org/licenses/by/3.0/). 